\title{
Towards Invariant Meanings of Spatial Prepositions and Preverbs
}

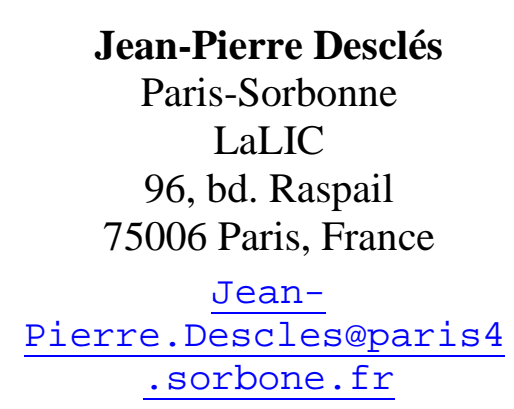

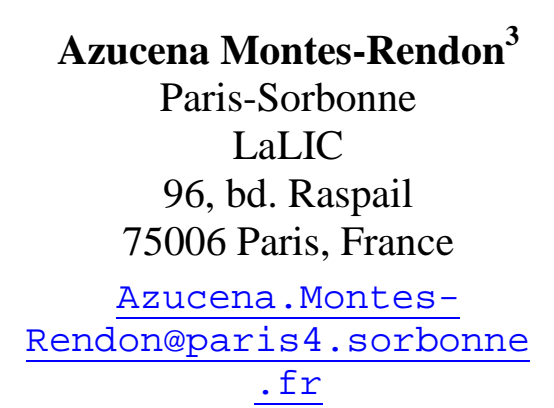

\begin{abstract}
This work presents the semantical analysis of the two spatial prepositions and associated prefixes, the French sur, sur- (on) and the Polish przez, prze- (across). We propose a theory of abstract places (loci), as a method of description which helps to build an invariant meanings of the two linguistics units.
\end{abstract}

\section{Introduction}

Natural languages encode spatial and temporal representations in many various ways (deictics, prepositions, verbal lexicon and preverb). This article presents analyses of the two prepositions and associated preverbs, the French sur, sur-(on) and the Polish przez, prze- (across). We are particularly interested in the way the preposition and preverb determine a place.

It is interesting to note that from a diacronical view point (Bally, Meillet, WitkowskaGutkowska) spatial prepositions become preverbs. Two problems arise : Is the meaning of the preverb composed with the meaning of lexical predicate? Does the meaning of the preverb have a prepositional origin? It is however impossible to present in this short article the results of our analysis; we show only the methods by means of two mentioned examples. We note that the work on other prepositions and preverbs in French, Polish and Spanish are in progress.

Many linguists (Benett, Culioli, Pottier, Talmy...) have recognized the necessity of quasi-topological analysis for studying space encoded by languages. However, it seems to us that the elementary topology as defined for mathematical analysis, does not capture exactly the linguistic problems in an adequated way. For instance, the idea of boundary as expressed by languages does not always refer to a point or limit. On the other hand, the understanding of a place cannot be reduced to the spatial notion. Indeed, from the cognitive point of view, natural languages use more abstract notion while referring to the place. Thus, we represent spatial place but also temporal and notional as, for instance, in Pottier's approach (Pottier:1992).

We propose a theory of abstract places called "Abstract Loci Theory". This theory uses operators like in Kuratowski's algebra for elementary topology (Engelking: 1989). However, in this article, the operators of interiority, exteriority, closure and boundary are defined with new properties such that we obtain a "quasi-topological" structure: the interiority and exteriority operators are not idempotent and the interiority of the boundary is not always empty. We note respectively INT, EXT, FRO, FER, the new operators of interiority, exteriority, boundary and closure in this Abstract Loci Theory. We propose to give an informal approach to the main aspects of this theory as it is in progress.

\footnotetext{
${ }^{1}$ The research was granted by Projet Cognitique "Espaces, langues et cognition" Ministère de la Recherche, Paris, France.

${ }^{2}$ Granted by the scholarship of French Government.

${ }^{3}$ Granted by ANUIES-SUPERA, Mexican Government.
} 
The notion locus refers to abstract place ( spatial or temporal or notional). Let $\Re$ be a referential domain and let the locus LOC be a part of $\Re$.

This locus LOC builds a partition of $\mathfrak{R}$ composed of three parts (see figure 1):

INT (LOC): interior locus of LOC;

EXT(LOC): exterior locus of LOC;

FRO(LOC): boundary locus of LOC between EXT(LOC) and INT (LOC).

The interior locus of LOC in Abstract Loci Theory has the following properties:

$\mathrm{INT}(\mathrm{INT}(\mathrm{LOC})) \subseteq \mathrm{INT}(\mathrm{LOC}) \subseteq \mathrm{LOC}$

If $\mathrm{LOC}_{1} \subseteq \mathrm{LOC}_{2}$ then INT $\left(\mathrm{LOC}_{1}\right) \subseteq \mathrm{INT}\left(\mathrm{LOC}_{2}\right)$

$\forall$ LOC, INT(LOC) $\neq \varnothing$

The exterior locus of LOC is such that it is included in the complement of LOC.

The closure locus of LOC is defined as:

$\operatorname{FER}($ LOC $)=\operatorname{INT}($ LOC $) \cup \operatorname{FRO}($ LOC $)$

with the following property:

FER(FER (LOC)) $\supseteq$ FER (LOC) $\supseteq$ LOC

Inside FRO(LOC) we distinguish two other loci, internal boundary and external boundary, such that : FRO-int $($ LOC $)=$ LOC $\backslash$ INT $($ LOC $)$

FRO-ext $($ LOC $)=$ FER $($ LOC $) \backslash$ LOC

The boundary locus is then defined as:

$\mathrm{FRO}(\mathrm{LOC})=\mathrm{FRO}-$ int $(\mathrm{LOC}) \cup \mathrm{FRO}-\operatorname{ext}(\mathrm{LOC})$

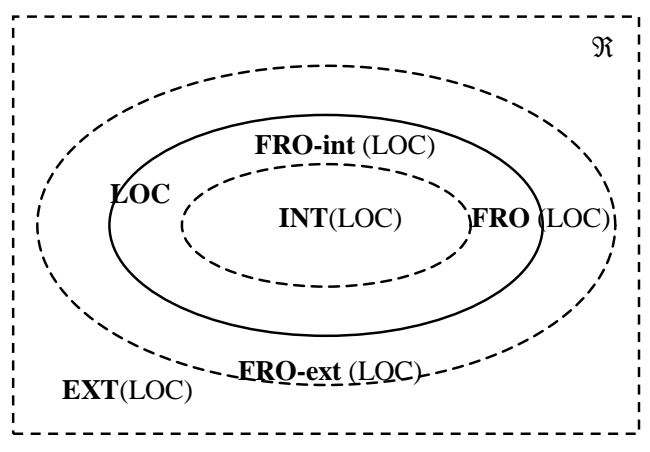

Figure 1

We introduce the "anchoring relation" (French: repérage) between the "anchored entity" (repéré) and the "anchor entity" (repère). This relation is in general non-symmetric (Desclés, Froidevaux: 1982, Culioli: 1990). The analysis of the meaning of the preposition is done by means of Abstract Loci Theory and anchoring relation, where the preposition determines an anchor (Flageul: 1997, Desclés: 1998a).

Our hypothesis is that it is possible to exhibit an invariant meaning in abductive process. We understand this invariant as cognitive representation which does not occur in natural languages (Desclés and alii: 1998).

We consider the syntactical compositionality as an application of verbal prefix to verbal predicate in order to build a complex predicate (e.g. surapplies to veiller for building a complex predicate surveiller) (Desclés: 1998a). However, on the representational level, the compositionality between the meaning of the preverb and that of the verb forms a new semantical construct; the result that cannot be described by a simple function, but is rather conceived as complex interaction between semantical units.

\section{$2 \quad$ Sur and Sur- in French}

\subsection{The French preposition sur (on)}

Let us analyze the prepositional examples by means of the above explained method. In the example below:

\section{(1) Le livre est sur la table}

The book is on the table

the preposition sur expresses the position of the entity the_book (anchored) to the surface of the_table (anchor) according to the high-low gradient (gravity) which is orthogonal to the 
anchor. There is a contact between these entities. The preposition sur indicates the external boundary locus- FRO-ext (the_table) of anchoring.

\section{(2) L'affiche est sur le mur}

The poster is on the wall

(3) La mouche est sur le plafond

The fly is on the ceiling

The preposition sur in (2) indicates the anchoring relation between the_poster (anchored) and in (3) FRO_ext of the_wall (anchor), the_fly and FRO_ext of the_ceiling. There is contact in these examples. The gradient is determined by some other kind of force, which is not gravity.

(4) Les ponts sur la Moselle

The bridges on the Moselle river

We can analyze the preposition sur in (4) like in (1) that is, we have the anchoring relation to FRO_ext of the_river according to the high-low gradient, without contact.

(5) Luc appuie sur une touche du piano Luc presses a key of the piano

$L u c$ controls the action considered as an oriented movement establishing a contact between his_hand and the FRO_ext of the piano_key The gradient is determined by the action expressed through the verb appuyer (to press).

\section{(6) Le regard de Jean tombe sur sa fille}

The glance of Jean falls on his daughter

Jean controls the oriented movement of his glance. This movement is directed to the external boundary locus of the visibility determined around his_daughter. Hence a gradient is determined by the orientation of the movement of his glance.

\section{(7) Je l'attends sur les onze heures}

I'm waiting for him around eleven o'clock

This is a temporal example where eleven_o'clock is an interval considered as anchor. The global vision of this temporal locus explains the meaning of the preposition sur, glossed as: "being over (FRO_ext) the locus around_eleven_o'clock".

We can describe the invariant meaning of the preposition sur as anchoring relation of an entity to the external boundary locus, FRO_ext(LOC), according to an orthogonal gradient. We note that the contact between the entities is not necessary.

\subsection{The French Preverb sur-}

The same analysis as for preposition is applied to the preverb sur-.

(8) L'avion survole Paris

-> The plane flies over Paris

The complex predicate survoler (to overfly) in (8) provides two pieces of information: one is related to the verb voler (to fly) and the other, to the preverb sur-. This preverb indicates that the position of movement of the plane is localized to the FRO_ext of Paris, according to the highlow gradient. There is no contact.

(9) Pierre surélève la table

-> Pierre raises the table over something

In this example, the preverb sur-indicates that the_table is put on the external boundary of a higher place (FRO_ext).

\section{(10) La lanterne surmonte la porte}

-> The lantern is over the door

In (10), the glance of any observer starts from the low part of the_door and rises up, to visualize the_lantern which is on the FRO-ext of the superior part of the_door. Here, we have to do with static description.

(11) Le magasin surbaisse les prix des vêtements -> The shop lowers the prices beyond a threshold

The preverb sur- in (11) indicates that the action expressed by the verb baisser (to lower) is realized beyond the established threshold, that is, the verb is realized on the external boundary locus (FRO-ext of_threshold), the notional locus being organized by the prices.

\section{(12) Emilie suralimente son bébé}

$\rightarrow$ Emilie feeds her baby over the threshold

In (12), the process indicated by the accumulative verb alimenter (to feed) continues towards a boundary of accomplishment, this boundary being beyond a threshold (correct feeding of a baby). The preverb sur-indicates that the boundary is "above" the threshold. 
Consequently, the process goes over this threshold.

\section{(13) Luc surmonte ses problèmes}

-> Luc overcomes his problems

We analyze the meaning of (13) as follows: Luc is anchored to the abstract locus (the activity "being affected by problems"). The verb monter (to rise up) is used to show that $L u c$ becomes less and less affected by his_problems, until he becomes completely unaffected.
The spatial use of the preverb sur-, is oriented according to the high-low gradient (gravity) $(8,9,10)$ and the position above the external boundary of an anchor. In the other cases $(11,12,13)$, the preverb sur- indicates a position above the external boundary of locus, organized according to some gradient. The cognitive representation (see figure 2) shows the net meaning of preposition sur and preverb sur-, as well as the common invariant meaning of them.

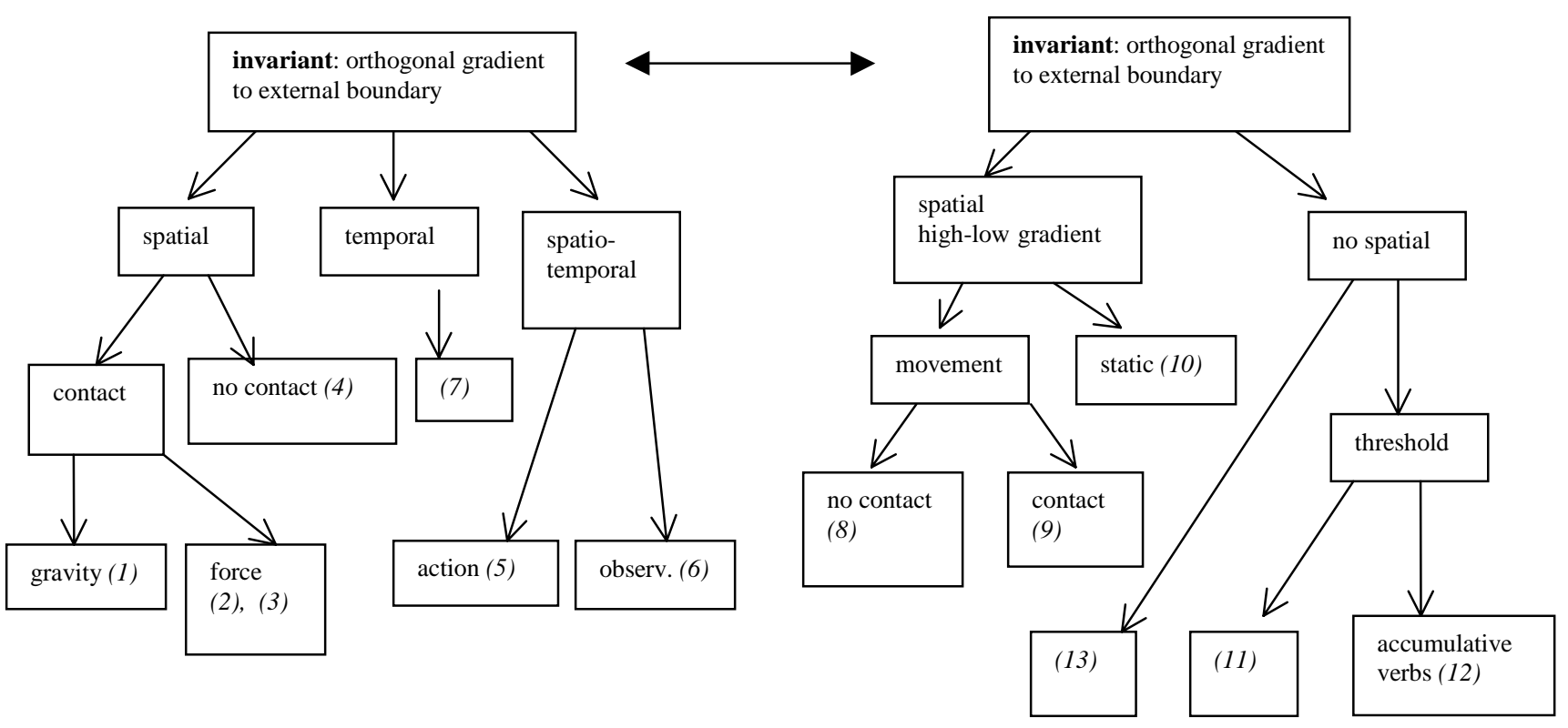

Net of prepositional meaning sur

Figure 2

Net of preverbal meaning sur-

\section{Przez and Prze- in Polish}

\subsection{Polish Preposition przez (across)}

The preposition przez in the example below expresses the idea of crossing the locus:

\section{(14) Sekwana płynie $\begin{gathered}\text { przez } \\ \text { Seine }\end{gathered}$
to flow aryż
across Paris \\ The Seine flows through Paris}

Parts of river pass through the locus Paris. We consider in (14) five salient phases of the passage: at the beginning of the process, the parts of river are localized to the exterior EXT(LOC), then to the boundary FRO(LOC), they arrive in the interior INT(LOC), passing again the boundary $\mathrm{FRO}(\mathrm{LOC})$, and coming out to EXT(LOC). The double passage through the boundary locus presupposes an orientation of this locus, imposed here by the flow of the river.

\section{(15)}

$$
\begin{array}{lll}
\text { Słońce } & \text { zaglaqda przez } & \text { okno } \\
\text { sun } & \text { to come in across } & \text { window }
\end{array}
$$

The sunshine comes in through the window

This example introduces an intermediate locus IME(LOC) inside the FRO(LOC) with FRO-ext and FRO-int, considered as locus of communication between EXT(LOC) and INT(LOC). The passage implies three salient phases of the movement. We note that 
IME(LOC) is encoded in natural languages as the privileged passage (door, window...).

\section{(16) Darek nie przychodził przez cały miesiąc not to come across whole month}

Darek has not come for the whole month

The meaning "crossing a locus" is present in (16) considering miesiàc (the month) as a locus of temporal nature. We pass through the boundary FRO(LOC) through interior INT(LOC) to the second boundary FRO(LOC), the locus being temporally oriented.

\section{$\begin{array}{cll}\text { (17) Przez } & \text { ciebie } & \text { zmęczyłam się } \\ \text { across } & \text { you } & \text { to get tired }\end{array}$ \\ I got tired because of you}

We analyze (17) using the intermediate locus IME(LOC), but on a more abstract level. Let us consider a domain related to the notion "tiredness". The exterior EXT(LOC) is related to "not being tired", while the interior INT(LOC), to "being tired". To pass from EXT(LOC) into INT(LOC), we need to cross IME(LOC), which refers to a notional locus "you". Consequently, three salient phases are taken into account.

\section{(18) Rozmawiałam z nim przez telefon. to speak with him across phone I spoke to him over (across) the phone}

We need to "cross" an instrument the_phone to reach another person, thus we also refer to the intermediate locus IME(LOC) in the domain of communication.

We have so far discussed the examples taking into account the meaning of the Polish preposition przez in regard to the proposed concepts of the Abstract Loci Theory. We may now structure those examples. On the one hand, we distinguish spatio-temporal, temporal and notional loci, and on the other hand, we have shown two related representations of the prepositional meaning: the one refers to crossing a locus, the other uses an intermediate locus while crossing. Based on these analyses, we consider an invariant meaning of the preposition przez as crossing a boundary locus.

\subsection{The Polish Preverb prze-}

We will now establish a similar analysis of preverbal examples prze-, in order to show an invariant meaning of the complex predicate. To simplify our study we omit the aspectual consideration of the preverb, taking into account only the relationship to the meaning of the preposition.

\begin{tabular}{|c|c|c|}
\hline (19) & $\begin{array}{l}\text { Przeszedł } \\
\text { across-to walk }\end{array}$ & $\begin{array}{l}\text { przez } \\
\text { across }\end{array}$ \\
\hline
\end{tabular}

We encounter here "crossing" the locus ulica (street) expressed by compositionality between the preverb prze- and the lexical predicate $i \hat{E}_{c}$ (to walk). Five salient phases are considered in (19): a passage from the exterior EXT(LOC) to the boundary $\mathrm{FRO}(\mathrm{LOC})$, then to the interior INT(LOC), next to another boundary FRO(LOC) for going out, to the exterior EXT(LOC). The locus ulica (street) is temporally oriented.

(20) Przelał wino z beczki do butelki
across-to pour wine from barrel to

He poured wine from the barrel into the bottle

The semantic description of (20) appeals to an intermediate locus $\operatorname{IME}(\mathrm{LOC})$, which is not specified here. The compositionality between prze- and laç (to pour) means that the entity (wine) is localized to exterior locus (barrel) and crosses the intermediate locus IME(LOC) to be localized to the interior INT(LOC) (the_bottle).

\section{(21) Anna przeczytała książkę across-to read book}

She read the book "across"/ She achieved her reading

The compositionality takes into account not only the preverb prze- and the predicate czytaç (to read), but also the object ksià"ka (the book). The action of reading is thus simultaneous to "crossing" the object the_book conceived as a locus. Thus, we consider three salient phases: boundary FRO(LOC) (the beginning of the book), interior INT(LOC) and boundary FRO(LOC) (the end of the book and the end of reading, in the sense achievement of this action).

$$
\begin{aligned}
& \begin{array}{l}
\text { Przemalowała ściany na } \\
\text { across-to paint }
\end{array} \text { wall into green } \\
& \text { She has repainted the wall in green }
\end{aligned}
$$

The example (22) expresses the property change affecting an objet. In the domain related to colors, we consider the first color as an exterior EXT(LOC). "To reach" the other color, considered as interior INT(LOC), we need to cross an unspecified intermediate locus IME(LOC). Changing the property is oriented in time.
(23) Matka
przekarmiła
dziecko 


\section{mother across-feed baby \\ The mother overfed the baby}

Some accumulative verbs (to salt, to cook) imply a change towards a threshold. The prefix prze- in connection to the predicate karmiç (to feed), indicates the passage from the exterior EXT(LOC), to which we associated the meaning "not enough", through intermediate locus IME(LOC). The amount of food in IME(LOC) is accurate. "Passing" into interior INT(LOC) is interpreted as "too much". The amount of food organizes these locus.

\section{(24) Jan przegrał wszystkie pieniądze w kasynie across-toplay all money in casino "Jan has played across all his money" Jan has lost all his money in casino}

The domain is related here to the game. We consider the passage from EXT(LOC) (having enough money) through the intermediate locus IME(LOC) (still having money) into the interior
INT(LOC) (having no money). The bet organizes the locus.

We organize now the preverbial examples in the way we did it for the preposition. We note that the preverb introduces a dynamic change while composed with the predicate. This is due to its perfectivizing role that we do not develop in this article. The examples (19) to (22), express the meaning "crossing" a locus or "crossing it through an intermediate locus". We encounter as well the explicit idea of going over a threshold $(23 \& 24)$. The invariant meaning for the preverb composed semantically with a predicate is thus crossing the boundary locus, the same as in the prepositional case. Given the analysis of preposition and the associated preverb, we can now establish the relation between the nets of meanings (see figure 3)

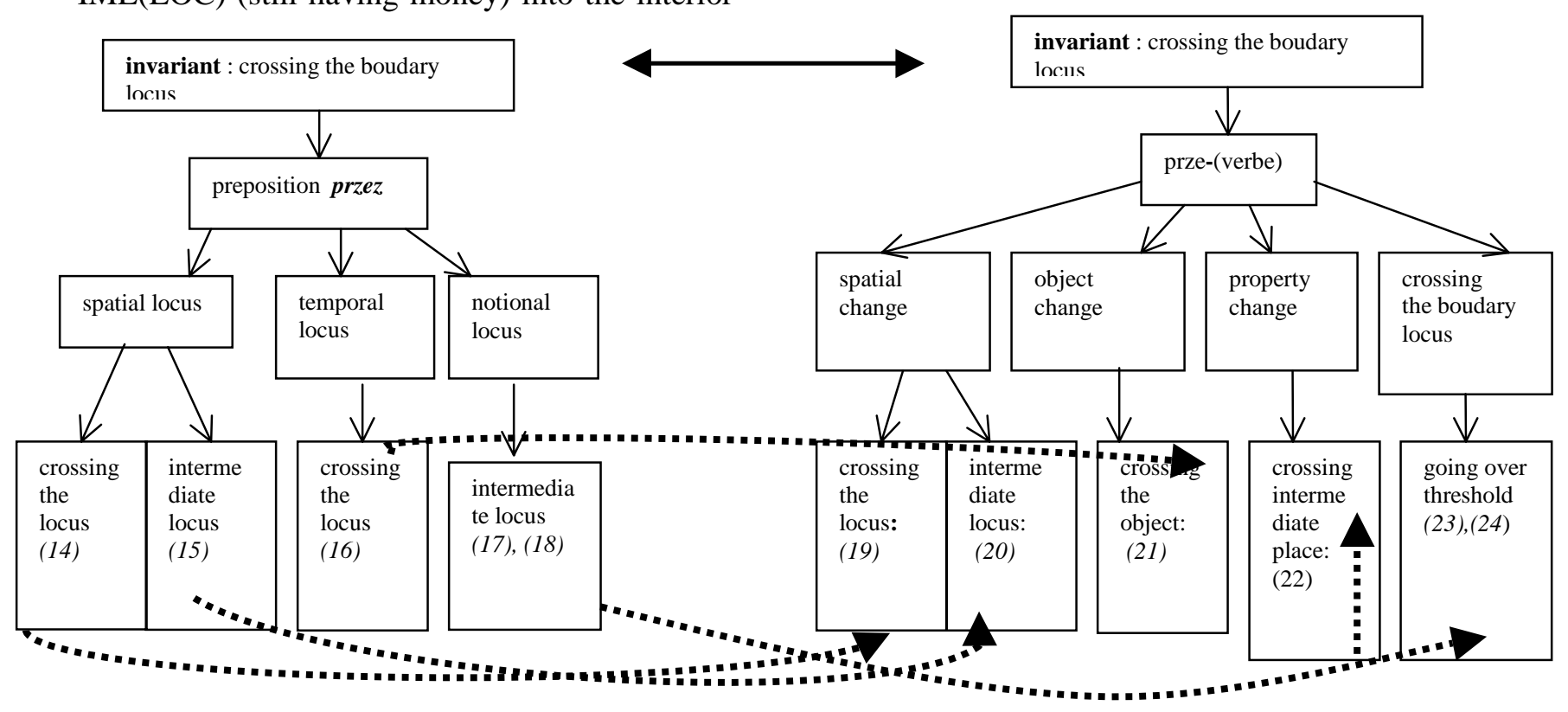

Net of prepositional meaning przez

Net of preverbal meaning prze-

Figure 3

\section{Conclusion}

The analysis of prepositional examples of sur, led us to establish an invariant meaning, which corresponds to anchoring to the external boundary locus with a gradient. The invariant meaning of the preposition sur corresponds to the invariant meaning of the preverb sur-.
This result seems more general than the analysis of C. Vandeloise (Vandeloise: 1985), as the resemblance family porteur-porté established in his work does not explain the examples (5)-(7) of sur. As for the Polish preposition przez and its associated preverb prze-, we managed to establish the same invariant meaning for the two linguistic units: it refers to "crossing the boundary locus". However, this analysis does not 
take into account the aspectual consideration of the prefix, which in Polish has a perfectivizing role; the same approach will be used in the semantical studies of aspect in Polish. Our results may be compared to the analyses for the preposition przez and preverb prze- obtained in the framework of the Langacker's grammar (Dabrowska: 1996), but the latter does not use any topological approach.

We claim that the invariant meaning is not universal across natural languages. Each natural language organizes its own cognitive representations (Desclés: 1998b) as it was shown, for example, by Bowerman (Bowerman: 1996), who compared different meanings of the preposition across few languages:

apple in bowl, b. handle on pan, c. bandaid on leg, d. right on finger, e. fly on door.

$\begin{array}{lllll}\quad \text { a } & \text { b } & \text { c } & \text { d } & \text { e } \\ \text { English in } & \text { on } & \text { on } & \text { on } & \text { on } \\ \text { French dans } & \text { de } & \text { sur } & \text { à } & \text { sur } \\ \text { Dutch aan } & \text { op } & \text { om } & \text { op } & \text { aan }\end{array}$

If we look now at the following sentences in English, Spanish, Polish and French:

(i) The book is on the table

(ii) El libro esta en la mesa

(iii) Książka jest na stole

(iv) Le livre est sur la table

The prepositions on, na, en in these examples are translated by the French sur. And yet, the analogues of sur in English, Spanish and Polish correspond only to a particular meaning of sur, the value given in (1). The invariant meanings of on, na, en are always defined within respective languages.

If we consider the preverbal examples:

(12) Emilie suralimente son bébé

$\rightarrow$ Emilie feeds her baby over the threshold

(23) Matka przekarmita dziecko The mother overfed the baby

we notice that the two sentences have the same state of affairs, but their cognitive construal is related to each language (French or Polish). Thus, in (12) the prefix sur-indicates the process that continues up to the degree situated over the threshold, while (23) indicates the passage from "not enough" to "going over the threshold". This passage is present in (12), however it is considered as a secondary effect.

In Fregean words: (12) and (23) have the same Sinn, but differ in Bedeutung.

\section{Bibliography}

BALLY, Charles. 1954. Linguistique générale et linguistique française. Francke, Bern.

BENNETT, D. C. 1975. Spatial and temporal uses of English Prepositions. London: Longman.

BOWERMAN, Melissa. 1996. "Cognitive versus linguistic determinants." In Gumperz \& Levinson (eds.). Rethinking linguistic relativity, pp. 144-176.

CULIOLI, Antoine. 1990. Pour une linguistique de l'énonciation. Opérations et représentations. Tome 1 . Ophrys.

DÑBROWSKA, Ewa. 1996. "The spatial structuring of events: A study of Polish perfectivizing prefixes." In Martin Pütz \& René Dirven (eds.). The Construal of Space in Language and Thought. Mouton de Gruyter. Berlin New York. pp. 467-489.

DESCLÉS, Jean-Pierre. 1998a. "Préposition spatiales, relateurs et préverbes." Actes du Colloque Les relations, Lille, mars (in press).

DESCLÉS, Jean-Pierre. 1998b. "Les représentations cognitives du langage sont-elles universelles?" In Matteo Negro, (ed.). La réalité et le signe. Editions Universitaires, Fribourg, Suisse. pp. 53-81.

DESCLÉS, Jean-Pierre., FROIDEVAUX, Christine. 1982. "Axiomatisation de la notion de repérage abstrait." Mathématiques Informatique et Sciences Humaines, 78: 73-119.

DESCLÉS, Jean-Pierre., FLAGEUL, Valérie., KECKENBOSCH, Christiane., MEUNIER, Jean-Marc., RICHARD, JeanFrançois. 1998. "Sémantique de l'action." Langages, 132: 28-47.

ENGELKING, Ryszard. 1989. General Topology. Helderman Verlag. Berlin.

FLAGEUL, Valérie. 1997. Description sémantico-cognitive des prépositions spatiales $d u$ français. Thèse de doctorat. Université de Paris-Sorbonne. 
LANGACKER, Ronald. 1987, 1991. Foundations of Cognitive Grammar I, II. Standford: Standford University Press.

MEILLET, Antoine. 1937. Introduction à l'étude comparative des langues indoeuropéennes. Paris

POTTIER, Bernard. 1992. Sémantique générale. Presses Universitaires de France.

TALMY, Leonard. 1983. "How Language Structures Space" in H. Pick, L. Acredolo (eds), Spatial Orientation: Theory, Research and Application. New York: Plenum Press. pp. 22582.

VANDELOISE Claude. 1985. "Les prépositions SUR/SOUS et la relation PORTEUR/PORTE Leuvense Bijdragen 74 pp. 457-481.

WITKOWSKA-GUTKOWSKA, Maria. 1989. "Funkcje czasownikowego przedrostka przy- w porownaniu z funkcjami przyimka przy w jezyku polskim." Acta Universitatis Lodziensis; Folia Linguistica 21. 